\section{'LSU Gold' Fig}

Ed O'Rourke, ${ }^{1}$ Charles E. Johnson, ${ }^{2}$ and James E. Boudreaux ${ }^{2}$

Louisiana State University Agricultural Center, Department of Horticulture, 137 Julian C. Miller Hall, Baton Rouge, LA 70803-2120

\section{Wayne Bourgeois ${ }^{2}$}

Louisiana State University Agricultural Center, Citrus Research Station, Louisiana State University, 22193 Highway 23, Sulphur, LA 70083

'LSU Gold' is the second fig cultivar (Ficus carica L.) released from the Louisiana State University Agricultural Center fig breeding program. A fig breeding program was initiated in the 1950s to develop cultivars for the gulf south region. During this period (O'Rourke, 1992) crosses were made and seedlings evaluated for adaptation. In 1994 we initiated a project with the intent of reestablishing a research orchard containing the elite selections from the original breeding program. The purpose of this project was to evaluate the varietal potential of the remaining selections. Trees for this project were propagated from reliable sources that had maintained trees from the original plantings. Trees were grown alongside recommended commercial cultivars for comparison of fruiting characteristics. Morphological characteristics of the putative selections were carefully compared to original notes and photographs to insure proper identification. Comparative ratings were made of each cultivar and selection independently. Evaluations and comparisons were made between trees of same age and cultural management in same orchard. Breeding selection designated L59-46-63 was evaluated in orchards alongside currently recommended cultivars at research stations located at Port Sulfur, Hammond, St.Gabreil and Baton Rouge, La., from 1996 to 2002 and chosen for release because of superior fruiting characteristics.

\section{Parentage}

'LSU Gold' is a selection from a group of seedlings derived from a cross of 'Celeste' $x$ L55-13-39. The cross was made in 1959 and the selection made by Ed O'Rourke in 1961 and tested as L59-46-63. The complete pedigree is presented in Fig. 1.

\section{General Description}

'LSU Gold' produces large (45 g) yellow fruit, 37.5 to $50 \mathrm{~mm}$ in diameter, of good quality. The yellowish-green fruit of 'LSU Gold'

Received for publication 8 July 2003. Accepted for publication 21 Aug. 2003. Louisiana State University $\mathrm{Ag}$ Center journal series 01-28-0660. We appreciate technical assistance and advise of Kristi Whitley. We thank David Himelrick, Jeff Kuehny, and E.W. Bush for manuscript review.

${ }^{1}$ Distinguished professor emeritus.

${ }^{2}$ Professor of horticulture. To whom reprint requests should be addressed; e-mail cejohnson@agctr.lsu. edu.

${ }^{3}$ Professor:
(Fig. 2) are wider than long in a inverse deltoid shape and taper abruptly toward the stem end with no neck (Table 1). The flat top fruit has a partially open eye (ostiole) on mature fruit. Internal color is light red to pink when soft ripe (Table 2). Fruit ripen about 3 to $7 \mathrm{~d}$ before 'Celeste' or about the last week in June in the Baton Rouge area. The main crop fruit of cultivars.

${ }^{\mathrm{z}} \mathrm{L}=$ degree of lightness $100=$ pure white, $0=$ black.
'LSU Gold' ripens over a 15-d period, which is comparable to 'Celeste' and 'Florentine'. 'LSU Gold' produced11.0 kg on 5-year-old trees over a 2-year period (2000 and 2001) compared to $9.1 \mathrm{~kg} /$ tree for 'Celeste' for same age tree for the same period (data not shown). Trees of 'LSU Gold' are vigorous, producing upright trunks with slight tendency to produce horizontal growth in juvenile stage. Foliage cover is sparse when compared to 'Celeste' in that trunks and branches of 'LSU Gold' are still visible after full foliation in midseason. The mature leaves of 'LSU Gold' are palmate with five distinct lobes. The primary lobe is obovate shaped on a mature leaf. The margin of the leaf on the basal lobes of "LSU Gold" is serrulate. The leaf base is hastate.

Fruit of all currently recommended cultivars of figs will split and crack to some degree during the ripening stage when excessive moisture is present. Notations on deep radial cracks

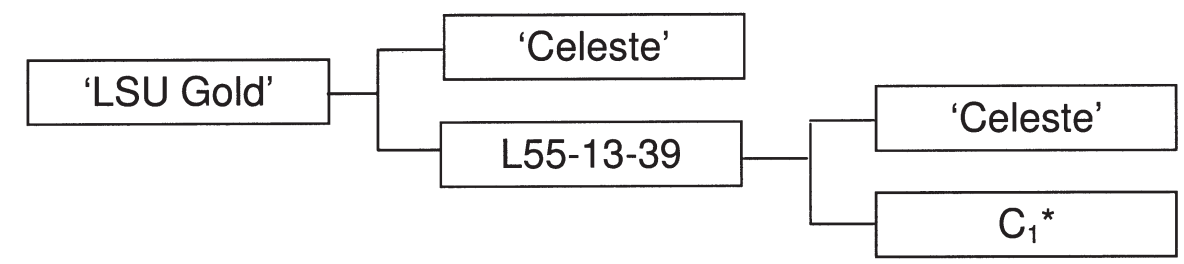

Fig 1. Pedigree of 'LSU Gold' (L59-46-63). $\mathrm{C}_{1}=$ unnamed Capri fig from California.

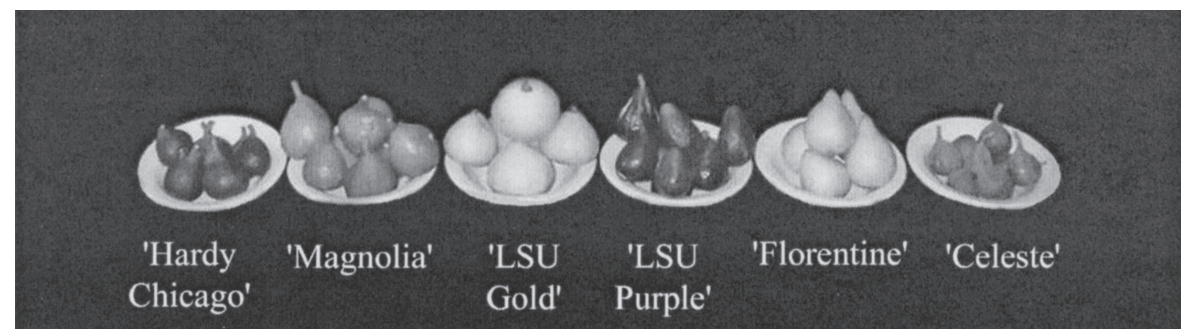

Fig 2. Fruit of 'Hardy Chicago', 'Magnolia', 'LSU Gold', 'LSU Purple', 'Florentine', and 'Celeste' fig

Table 1. Comparison of fruit characteristics 'LSU Gold' to several fig cultivars.

\begin{tabular}{llcllc}
\hline & $\begin{array}{c}\text { Length } \\
\text { to } \\
\text { width } \\
\text { ratio }\end{array}$ & $\begin{array}{c}\text { Wt } \\
(\mathrm{g})\end{array}$ & $\begin{array}{c}\text { Length } \\
(\mathrm{mm})\end{array}$ & $\begin{array}{c}\text { Width } \\
(\mathrm{mm})\end{array}$ & $\begin{array}{c}\text { Soluble } \\
\text { solids } \\
\%\end{array}$ \\
\hline Entry & $0.77 \mathrm{c}^{2}$ & $12.6 \mathrm{c}$ & $35.5 \mathrm{ab}$ & $27.3 \mathrm{c}$ & $21.9 \mathrm{a}$ \\
LSU Purple & $0.73 \mathrm{c}$ & $18.6 \mathrm{bc}$ & $43.1 \mathrm{~b}$ & $31.8 \mathrm{bc}$ & $20.2 \mathrm{~b}$ \\
LSU Gold & $1.14 \mathrm{a}$ & $43.6 \mathrm{a}$ & $41.0 \mathrm{ab}$ & $46.7 \mathrm{a}$ & $12.2 \mathrm{c}$ \\
Florentine & $0.80 \mathrm{bc}$ & $28.1 \mathrm{~b}$ & $45.1 \mathrm{a}$ & $36.2 \mathrm{bc}$ & $18.7 \mathrm{~b}$ \\
Hardy Chicago & $0.84 \mathrm{~b}$ & $23.7 \mathrm{~b}$ & $40.9 \mathrm{ab}$ & $34.7 \mathrm{~b}$ & $14.8 \mathrm{c}$ \\
\hline
\end{tabular}

${ }^{2}$ Means followed by the same letter are not significantly different according to Tukey's test $(P \leq 0.05)$.

Table 2. Comparison of external and internal color measurements (color was measured by a Minolta CM3500d spectrophotometer) of 'LSU Gold' to several fig cultivars

\begin{tabular}{llrrrrrr}
\hline & & \multicolumn{5}{c}{ Color values } \\
\cline { 3 - 7 } & & \multicolumn{5}{c}{ External } \\
\cline { 3 - 7 } Entry & Color & \multicolumn{1}{c}{$\mathrm{L}^{\mathrm{y}}$} & $\mathrm{a}^{\mathrm{y}}$ & $\mathrm{b}^{\mathrm{x}}$ & $\mathrm{L}$ & $\mathrm{a}$ & $\mathrm{b}$ \\
\hline Celeste & Brown & $41.4 \mathrm{~b}^{\mathrm{w}}$ & $13.5 \mathrm{ab}$ & $17.1 \mathrm{~b}$ & $35.1 \mathrm{a}$ & $8.9 \mathrm{a}$ & $17.1 \mathrm{a}$ \\
LSU Purple & Purple & $23.8 \mathrm{c}$ & $4.2 \mathrm{bc}$ & $1.1 \mathrm{c}$ & $30.7 \mathrm{a}$ & $4.6 \mathrm{~b}$ & $18.1 \mathrm{a}$ \\
LSU Gold & Yellow & $66.5 \mathrm{a}$ & $-0.9 \mathrm{c}$ & $57.7 \mathrm{a}$ & $39.1 \mathrm{a}$ & $2.8 \mathrm{~b}$ & $20.7 \mathrm{a}$ \\
Florentine & Yellow & $70.9 \mathrm{a}$ & $-2.5 \mathrm{c}$ & $57.8 \mathrm{a}$ & $36.9 \mathrm{a}$ & $2.2 \mathrm{~b}$ & $20.5 \mathrm{a}$ \\
Hardy Chicago & Brown & $25.6 \mathrm{c}$ & $5.9 \mathrm{a}$ & $1.44 \mathrm{c}$ & $32.9 \mathrm{a}$ & $10.4 \mathrm{a}$ & $21.8 \mathrm{a}$ \\
\hline
\end{tabular}

$\mathrm{y}_{\mathrm{a}}=$ measurement of green to red on a scale of -80 to 100 , where $-80=$ green and $100=$ red.

${ }^{x} \mathrm{~b}=$ measurement of yellow to blue on a scale of -80 to 70 , where $-80=$ blue and $70=$ yellow.

${ }^{\text {w}}$ Means followed by the same letter are not significantly different $(P \leq 0.05)$. External measurements are

the means of five uniformly ripe fruit. Internal measurements from puree of five uniformly ripe fruit. 
radiating from the ostiole of 'LSU Gold' 1 to $3 \mathrm{~d}$ after heavy rain events have been made. Field ratings indicate that 'LSU Gold' has a greater tendency to have radial cracks when ripe than 'Celeste', but fewer than 'Florentine' and 'Magnolia'.

'LSU Gold' produces large figs that offer the producer a larger fruit for pick your own and local markets. This variety will not replace any currently recommended variety but offer a fruit with some unique marketing characteristics (Puls, 1995). Current trends in marketing are local farmers markets that offer fresh produce directly to consumers. The yellow color is somewhat unique and should present a marketing opportunity for pick your own and local markets. 'LSU Gold' commonly produces larger fruit than the current recommended varieties with good fruit quality. This selection should complement the recommendation list by increasing the diversity of fruit types. A marketing limitation that should be noted is the tendency of the fruit to have a partially open eye at maturity. Under humid conditions this could increase the amount of fruit spoilage. When the fruit is harvested at the proper stage for processing (firm ripe), this should not present a problem.

\section{Availability}

The LSU AgCenter does not have nursery trees of 'LSU Gold' available. Limited quantities of dormant cuttings are available from C.E.J for research. Commercial nurseries will be furnished dormant cuttings on first come basis for production of nursery trees

\section{Literature Cited}

O'Rourke, E.N. 1992. LSU Purple, a new fig for the Gulf South. La. Agr. 35(4):19-20.

Puls, E. 1995. Figs for commercial and home orchards in Louisiana. La. State Univ. Agr. Ctr. Publ. 1529. 